\title{
Lawful Domicile Under Section 212(c) of the Immigration and Nationality Act
}

Chief Judge Irving R. Kaufman of the Court of Appeals for the Second Circuit has noted "the striking resemblance between ... King Minos's labyrinth in ancient Crete . . . and the Immigration and Nationality Act"1 and has felt it necessary to summon up "Thesean courage" to interpret certain of its provisions." Such complexity has often produced disagreements among the circuits concerning the proper interpretation of various sections of the Act. ${ }^{3}$ The most recent of these disagreements concerns section 212(c), ${ }^{4}$ which establishes eligibility requirements for discretionary waiver by the Attorney General ${ }^{b}$ of statutory inadmissibility of

18 U.S.C. $\S \S 1101-1503$ (1976 \& Supp. II 1978).

2 Lok v. INS, 548 F.2d 37, 38 (2d Cir. 1977). See also Higham, American Immigration Policy in Historical Perspective, 21 L. \& ConTEMP. Prob. 213, 213 (1956) (describing immigration law as a "vast, chaotic, tremendously intricate mass of legislation"); Wasserman, The Undemocratic, Illogical and Arbitrary Immigration Laws of the United States, 3 INT'L LAw. 254, 254 (1969) ("The immigration statutes . . . are among the worst, longest, most ambiguous, [and] complicated . . . laws in the world") (Mr. Wasserman is a former member of the Board of Immigration Appeals).

3 For example, in addition to the controversy discussed in this comment, the Second and Ninth Circuits have been in conflict at least 10 other times in the past over provisions of the Act or its predecessors. Compare United States ex rel. Mignozzi v. Day, 51 F.2d 1019 (2d Cir. 1931) with Fong Haw Tan v. Phelan, 162 F.2d 663 (9th Cir. 1947), rev'd, 333 U.S. 6 (1948); compare DiPasquale v. Kanuth, 158 F.2d 878 (2d Cir. 1947) with Del Guarico v. Delgadillo, 159 F.2d 130 (9th Cir.), rev'd sub nom. Delgadillo v. Carmichael, 332 U.S. 388 (1947); compare Fong v. INS, 308 F.2d 191 (9th Cir. 1962) with Foti v. INS, 308 F.2d 779 (2d Cir.), rev'd, 375 U.S. 217 (1963); compare Grubbles v. Hoy, 261 F.2d 952 (9th Cir. 1958) with Costello v. INS, 311 F.2d 343 (2d Cir. 1962), rev'd, 376 U.S. 120 (1964); compare Errico v. INS, 349 F.2d 541 (9th Cir. 1965), aff'd, 385 U.S. 214 (1966) with Scott v. INS, 350 F.2d 279 (2d Cir. 1965), rev'd sub nom. INS v. Errico, 385 U.S. 214 (1966); compare Lee Fook Chuey v. INS, 439 F.2d 244 (9th Cir. 1970) with Reid v. INS, 492 F.2d 251 (2d Cir. 1974), aff'd, 420 U.S. 619 (1975); compare Garcia-Gonzales v. INS, 344 F.2d 804 (9th Cir. 1965) with Rehman v. INS, 544 F.2d 71 (2d Cir. 1976); compare Frias-Deleon v. INS, 547 F.2d 142 (2d Cir. 1976), cert. denied, 434 U.S. 841 (1977) with Cacho v. INS, 547 F.2d 1057 (9th Cir. 1976); compare United States v. Gasca-Kraft, 522 F.2d 149 (9th Cir. 1975) with United States v. Pereira, 574 F.2d 103 (2d Cir.), cert. denied, 439 U.S. 847 (1978); compare Francis v. INS, 532 F.2d 268 (2d Cir. 1976) with Nicholas v. INS, 590 F.2d 802 (9th Cir. 1979).

\& 8 U.S.C. $\$ 1182(\mathrm{c})(1976)$.

- The Attorney General is charged with the administration and enforcement of the Act (excepting those duties given to the Department of State). 8 U.S.C. $\$ \S 1101(a)(34), 1103(a)$ (1976). He has largely delegated his duties to the Immigration and Naturalization Service ("INS") and its officers. 
aliens. The Second Circuit has held that seven consecutive years of lawful domicile in any status will qualify a current permanent resident alien for such consideration, ${ }^{6}$ while the Ninth Circuit, expressly disagreeing, has held that section 212(c) requires the alien to have been a permanent resident alien (as defined in the Act) ${ }^{z}$ for the entire seven-year period. ${ }^{8}$ This comment examines the legislative history, statutory setting, and purpose of section 212(c) and concludes that the Second Circuit's more expansive interpretation is the proper one.

\section{BACKGROUND}

\section{A. Section $212(c)$}

\section{The distinction between grounds for exclusion ${ }^{9}$ and grounds}

- Lok v. INS, 548 F.2d 37 (2d Cir. 1977).

7 The Act defines the phrase "lawfully admitted for permanent residence" as the "status of having been lawfully accorded the privilege of residing permanently in the United States as an immigrant." 8 U.S.C. $\$ 1101(a)(20)(1976)$. In this comment, "lawful permanent resident" or simply "permanent resident" refers to an alien in such a status and "lawful permanent residence" refers to the status itself. It should also be noted that a "permanent resident" is only one type of "immigrant," although these two terms are sometimes used interchangeably in practice; an "immigrant" is defined as any alien who is not a nonimmigrant, id. § 1101(a)(15), and thus, apparently, also includes illegal aliens, refugees, and parolees.

${ }^{8}$ Castillo-Felix v. INS, 601 F.2d 459 (9th Cir. 1979).

- There are 33 classes of excludable aliens, more easily comprehended when they are broken down into seven categories.

I. Aliens who are physically or mentally deficient because of: (i) mental retardation, 8 U.S.C. § 1182(a)(1) (1976); (ii) present insanity or prior attacks of insanity, id. § 1182(a)(2), (3); (iii) sexual deviation, psychopathic personality or mental defect, id. $\S 1182(a)$ (4); (iv) drug addiction or alcoholism, $i d$. $\$ 1182(a)(5)$; or (v) affliction with any dangerous contagious disease, $i d$. $\$ 1182(\mathrm{a})(6)$.

II. Aliens who are economically undesirable because of: (i) present or prospective inability to earn a living, id. $\S 1182(\mathrm{a})(7),(8),(15)$; or (ii) because their employment in the United States may adversely affect similarly employed United States citizens or other aliens who have already immigrated, id. § 1182(a)(14), (32).

III. Aliens who are undesirable because of: (i) prior commission of a crime involving moral turpitude, id. § 1182(a)(9); (ii) prior conviction of two or more offenses involving a sentence of five years or more, $i d$. $\S 1182(a)(10)$; (iii) prior conviction of any crime related to possession of or trafficking in narcotic drugs or marijuana, id. § 1182(a)(23); (iv) practicing or advocating polygamy, $i d$. $\$ 1182(a)(11)$; (v) prostitution or connection with commercialized vice, $i d$. $\$ 1182(a)(12)$; or (vi) intent to engage in immoral sexual acts, $i d$. § 1182(a)(13).

IV. Aliens over 16 who are illiterate. $I d$. $\$ 1182(\mathrm{a})(25)$.

V. Aliens who are politically undesirable because: (i) they seek to engage in activities prejudicial to the public interest, $i d$. $\S 1182(\mathrm{a})(27)$; (ii) they are communists, subversives, or affiliated with any totalitarian party, $i d$. $\$ 1182(\mathrm{a})(28)$; (iii) they might engage in subversive activity, $i d . \S 1182(\mathrm{a})(29)$; or (iv) they were participants in Nazi persecutions between 1933 and 1945, id. $\S 1182(\mathrm{a})(33)$ (Supp. II 1978). 
for deportation ${ }^{10}$ is central to the scheme of the Immigration and Nationality Act; the former grounds are much stricter and more numerous than the latter. ${ }^{11}$ Because the grounds for exclusion are applicable each time an alien reenters this country, ${ }^{12}$ a resident alien who has committed an excludable offense can be denied reentry after traveling abroad even though he might not have been subject to deportation had he never left. For example, an alien cannot be deported on account of a mental disease, but he can be denied reentry on that ground. Moreover, excludable offenses are applicable regardless of how long the alien has lived in the United States. ${ }^{13}$ Thus an unwitting alien who lawfully enters the country, has an attack of insanity, is subsequently cured, and years later makes a brief visit to his homeland can find himself barred from returning to his job and family. To relieve aliens from this poten-

VI. Aliens failing to comply with documentary entry requirements, who have been previously excluded or deported, or who accompany or aid other defective entrants. Id. § 1182(a)(16)-(21), (30)-(31) (1976).

VII. Aliens who are ineligible for citizenship or who have avoided military service. Id. $\S 1182(a)(22)$. See generally U.S. Dep'T OF JUSTICE, IMMigration and Nationality Service, Guide to Immigration Benefits A-34 - A-37 (1977).

10 There are nineteen grounds for deportation. Following the grouping in note 9 supra, they include:

II. Becoming institutionalized or a public charge within five years of entry from causes extant at time of entry. 8 U.S.C. $\$ 1251(a)(3)$, (8) (1976).

III. Conviction and one-year confinement for a crime involving moral turpitude within five years of entry, conviction of two crimes involving moral turpitude regardless of sentencing or period of residence, conviction of any drug offense, prostitution or pimping, and conviction for illegal possession of certain firearms. Id. § 1251(a)(4), (11), (12), (14), (18).

V. Advocacy or affiliation with anarchy or communism, advocacy of the destruction of property or of the assaulting of officers, and prior participation in Nazi persecution. Id. $\S$ 1251(a)(6), (7), (15)-(17); id. § 1251(a)(19) (Supp. II 1978).

VI. Defective entry, violating nonimmigrant status, and failing to register. id. $\S 1251(\mathrm{a})(1),(2),(5),(9),(10),(13)(1976)$.

1 Compare the grounds for exclusion listed in note 9 supra with the grounds for deportation listed in note 10 supra. Note in particular that all grounds in category I (mental or physical defects) apply to exclusion only. Also, the mere likelihood either of indigency or subversive advocacy, for example, is sufficient to exclude whereas actually being on the welfare rolls or engaging in subversive advocacy is necessary for deportation. Only failure to register and conviction of illegal possession of firearms are grounds for deportation without also being grounds for exclusion.

12 This basic principle is not clearly stated in the statute. Under 8 U.S.C. § 1182(a) (1976), the grounds for exclusion bar aliens from "admission." "Admission" is not defined, however; apparently it has the same meaning as "entry," because id. § 1251(a)(1) makes entry when excludable a ground for deportation. "Entry" is defined as any coming of an alien into the United States. Id. \& 1101(a)(13). This latter definition is a codification of the Court's decision in United States ex rel. Volpe v. Smith, 289 U.S. 422 (1933).

1s There is no statute of limitations for excludable or deportable offenses. Gordon, The Need to Modernize Our Immigration Laws, 13 SaN Drego L. Rev. 1, 5-6, 18-20 (1975). 
tial hardship, ${ }^{14}$ Congress enacted section $212(\mathrm{c})$ :

Aliens lawfully admitted for permanent residence who temporarily proceeded abroad voluntarily and not under an order of deportation, and who are returning to a lawful unrelinquished domicile of seven consecutive years, may be admitted in the discretion of the Attorney General without regard to the provisions of paragraphs (1) to (25), (30), and (31) of subsection (a) of this section. ${ }^{15}$

Because the number of permanent resident aliens who have committed excludable offenses and then temporarily left the country after a domicile of seven years is rather small, section 212(c) was, until recently, not often invoked. ${ }^{16}$ This state of affairs came to an end in 1976 when the Second Circuit held in Francis v. INS ${ }^{17}$ that the equal protection clause of the Constitution ${ }^{18}$ requires that section 212 (c) relief be available in deportation cases even where the alien has not traveled abroad. ${ }^{19}$ The result of this judicial re-

14 See S. REP. No. 355, 63d Cong., 2d Sess. 6 (1914) ("it seems only just and humane . . . to permit the readmission to the United States of aliens who have lived here for a long time and whose exclusion after a temporary absence would result in peculiar or unusual hardship"). For the legislative history of the seventh proviso, predecessor to section 212(c), see text and notes at notes 46-47 infra.

It should be noted that section 212(c) goes farther than is necessary to relieve aliens of this hardship because it allows waiver of virtually all grounds for exclusion, see note 15 infra, including some grounds that would also be grounds for deportation, see notes 9-11 supra.

188 U.S.C. § 1182(c) (1976). The cited paragraphs-(1)-(25), (30), and (31)-include all the various grounds for the exclusion of aliens, see note 9 supra, with the exception of those found in paragraphs (26)-(29) and (32), which exclude undocumented nonimmigrants, subversives, and certain medical professionals, $i d$. $\$ 1182(\mathrm{a})(26)-(29),(32)$.

16 See Gordon, supra note 13 , at 7.

17532 F.2d 268 (2d Cir. 1976).

1s U.S. Const. amend. V.

10 The temporary-absence requirement still holds, of course, in exclusion cases.

The rationale for the Francis holding was that because section 212(c) occasionally granted relief to returning aliens whose offenses were deportable as well as excludable ones, see notes 11, 14-15 supra, it would be a denial of equal protection to withhold relief from other deportable aliens simply because they had never traveled abroad and attempted to return. 532 F.2d at 270-71. For example, if an immigrant committed an offense that was both deportable and excludable, left the country for a short time, returned, and then faced deportation proceedings, section 212 (c) would be applied retroactively, nunc pro tunc, to the time of the last entry. See, e.g., In re G.A., 7 I. \& N. Dec. 274 (1956). Waiver of the offense for purposes of exclusion was held ipso facto to effect a waiver of the offense for purposes of deportation. See id. at 275; In re L., 1 I. \& N. Dec. 1, 6 (1940). But cf. In re Wolf, 12 I. \& N. Dec. 736 (1968) (Attorney General cannot waive a defect under section 212(c) for all future entries but must do so only for limited periods of time). If the alien had not left the country and returned, however, he would not have been eligible for relief.

The Second Circuit did not consider the possibility of withholding section 212(c) relief 
writing of section 212(c) is that whether an alien is being excluded or deported, the grounds for such action can be waived if they are among those enumerated in subsections (1)-(25), (30), and (31) of section $212(\mathrm{a})^{20}$ and the alien is otherwise qualified. ${ }^{21}$

\section{B. The Instant Controversy}

To qualify for consideration for discretionary relief under section 212(c), the alien must be "lawfully admitted for permanent residence" and must have a "lawful unrelinquished domicile of seven consecutive years."22 These two phrases appear in the section as separate and independent conditions; there is no indication that the first phrase is intended to qualify or limit the second so as

altogether from deportation proceedings as a means of alleviating the disparate treatment of deportable immigrants. This probably would have been the preferable approach, particularly because one of the reasons for the original expansion of section 212(c) relief to deportation proceedings was that, at the time, there was no other avenue for obtaining discretionary waiver of grounds for deportation. See In re L., 1 I. \& N. Dec. 1, 3 (1940).

${ }^{20}$ The Board of Immigration Appeals ("BIA") held in a recent decision that although Francis expanded the class of aliens to which section 212(c) applied, it "did not increase the statutory grounds to which section 212(c) relief may be granted." In re Granados, 16 I. \& N. Dec. 726, 728 (1979). In Granados, the alien was deportable because he had been convicted for possession of a sawed-off shotgun, a ground for deportation but not for exclusion. Id. at 727.

21 The Ninth Circuit apparently is in conflict with the Francis decision, see CastilloFelix v. INS, 601 F.2d 459, 462 n.6 (9th Cir. 1979), but has yet to discuss the issue fully. It is not yet clear whether the INS will apply the Francis rule nationwide or limit it to cases arising outside the Ninth Circuit. See In re Silva, 16 I. \& N. Dec. 26, 30 (1976) (adopting the Francis rule); Kramer, Waivers Related to Grounds of Exclusion, Sections 212(a)(9), (15), (19) and (23), Immigration and Nationality Act, 56 INTERPRETER RELEASES 527, 531 n.** (1979) (BIA has indicated in unreported decisions that it will not apply the Francis rule in the Ninth Circuit); Memorandum from Paul W. Schmidt, INS Deputy General Counsel, to David L. Milhollan, BIA Chairman (Feb. 19, 1980), reprinted in 57 INTERPRETER RELEases 130, 132 (1980) (noting that the INS follows Francis even in the Ninth Circuit and asking the BIA to do the same).

32 The first of the phrases is defined in 8 U.S.C. $\$ 1101(\mathrm{a})(20)$ (1976). See note 7 supra. The second goes undefined in the Act but case law is of some help in defining its terms. The "lawfulness" of the domicile does not terminate until an adjudication of deportability. In re Lok, File No. A-31327663 (B.I.A. Nov. 8, 1979) (unreported), summarized in 57 INTERpRETBR RELEASEs 127-28 (1980); In re Hinojosa, No. 2718, slip op. at 5 (B.I.A. July 10, 1979) (dictum). For a discussion of "unrelinquished," see In re Carrasco, 16 I. \& N. Dec. 195 (1977).

Although at least one commentator has argued that no distinction was intended between "residence" (defined in the Act at 8 U.S.C. $\S 1101$ (a)(33) (1976)) and "domicile," Kramer, supra note 21 , at 530 , this comment will presume that the traditional definition of domicile applies, ramely, residence in fact plus an intention to remain permanently or indefinitely. See Anwo v. INS, 607 F.2d 435, 437 (D.C. Cir. 1979) (per curiam). The seven-year period may be perfected during a temporary absence from the country. In re C., 1 I. \& N. Dec. 631 (1944). 
to require that all seven years of the "lawful domicile" be in a "permanent resident" status. ${ }^{23}$ Thus section $212(\mathrm{c})$, according to its own terms as defined elsewhere in the Act, ${ }^{24}$ seemingly would admit of only one reading: any alien currently a "permanent resident," regardless of when or how such status was obtained, is eligible for relief provided he has maintained an unrelinquished "lawful domicile" of seven years' duration. Notwithstanding this apparent lack of ambiguity in the statutory language, neither the Board of Immigration Appeals ("BIA") ${ }^{25}$ nor any court that has considered this issue to date has treated the question so simply. ${ }^{28}$

Thus, one year after the passage of section 212(c), the BIA in In re $S .{ }^{27}$ adopted the more restrictive interpretation of the section, stating that "[i]n view of the plain language of section 212(c) ... together with the review of the historical background of the legislation ... we construe the section to mean that the alien . . . must have resided in this country for seven consecutive years subsequent to [a] . . . lawful admission for permanent residence."28 "Lawful domicile" was thus interpreted to mean lawful domicile as a permanent resident; an alien could count toward his seven years only those years spent in a permanent resident status.

The federal courts were not forced to choose between these two interpretations until 1977, when Chief Judge Kaufman of the Second Circuit wrote the opinion in Lok $v$. INS, ${ }^{29}$ adopting the

2s "The I.N.S. concedes that the bare wording of the statute does not require the alien to accumulate his seven years of domicile after he is admitted to the country on a permanent basis." Lok v. INS, 548 F.2d 37, 39 (2d Cir. 1977).

34 See text and note at note 7 supra; note 22 supra.

25 The BIA is an entity separate from the INS, see Roberts, The Board of Immigration Appeals: A Critical Appraisal, 15 SAN Drego L. Rev.'29, 29-30 (1977), deriving its authority by delegation from the Attorney General. Its function is to review certain administrative rulings made initially by special inquiry officers (also known as "immigration judges," 8 C.F.R. $\S 1.1(1)(1977)$ ), and its decisions are binding on the INS. 8 C.F.R. $\$ \S 3.1(b)(1)-(8)$, 3.1(g), 103.3(3), 103.9(a) (1980). Therefore, a BIA holding may be referred to as the INS position although the INS actually may have argued contrary to such a position when it first went before the Board.

${ }^{28}$ The instant controversy presents an interesting jurisprudential question (though one beyond the scope of this comment), namely, whether a court should apply the literal terms of a statute to resolve a problem, see note 23 supra, even though the statute was never considered by its makers as speaking to that question, see text and notes at notes 43-63 infra. As indicated in text, no tribunal has yet done so; indeed, most have inaccurately characterized the section as "ambiguous." See, e.g., Castillo-Felix v. INS, 601 F.2d 459, 464 (9th Cir. 1979); Lok v. INS, 548 F.2d 37, 39 (2d Cir. 1977).

275 I. \& N. Dec. 116 (1953).

${ }^{28} \mathrm{Id}$. at 118 (emphasis added).

s9 548 F.2d 37 (2d Cir. 1977). 
more expansive interpretation seemingly mandated by the language of section 212 (c).$^{\text {so }}$ Instead of relying on this language, however, the holding was grounded primarily in the legislative history of the Act, and it stressed two policy concerns: the statute should be read so as to effectuate its ameliorative purpose, and ambiguous deportation statutes generally should be construed in favor of the alien. ${ }^{31}$

The BIA did not welcome the Lok decision with the same hospitality it had shown toward Francis..$^{32}$ In In re Anwo, ${ }^{33}$ it declined to adopt the Second Circuit's holding "in cases arising outside of the Second Circuit," position declared twenty-six years earlier in In re S.5 The Ninth Circuit subsequently affirmed the BIA's position in Castillo-Felix v. INS. ${ }^{38}$ In extensive rebuttal of the Second Circuit, Judge Wright reasoned for the majority that because the language of the statute was "ambiguous" and the legislative history was unclear, ${ }^{37}$ the court should accord great deference to the long-standing BIA administrative interpretation, absent a showing of frustration of congressional purpose. ${ }^{38}$ In addition, he noted that since most nonimmigrants are precluded by the terms of their admission from lawfully harboring an intent to remain permanently and, thus, from maintaining a lawful domicile, only a small, elite group could benefit from the $L o k$ interpretation in any event. ${ }^{39}$

Although it is true that this controversy has significance only to the extent that there exist aliens who are not permanent residents, yet who are able to maintain a lawful domicile, Judge Wright's intimation that the issue is trivial because such aliens

so See text and notes at notes 23-26 supra. The court held that not having seven years of lawful permanent residence did not preclude Tim Lok from consideration for section 212(c) relief, remanding the case for determination whether Lok's domicile was lawful. 548 F.2d at 41. On remand, Lok's domicile was found unlawful. In re Lok, File No. A-31327663 (B.I.A. Nov. 8, 1979) (unreported), summarized in 57 INTERPRETER RELEASEs 127-28 (1980).

s1 Lok v. INS, 548 F.2d 37, 39-41 (2d Cir. 1977).

32 See note 21 supra.

s3 16 I. \& N. Dec. 293 (1977), aff'd per curiam, 607 F.2d 435 (D.C. Cir. 1979).

34 Id. at 298. The BIA reaffirmed this holding in In re Newton, No. 2733, slip op. at 3-6

(B.I.A. Oct. 5, 1979), and in In re Kim, No. 2735, slip op. at 3 (B.I.A. Sept. 27, 1979).

${ }^{33} 5$ I. \& N. Dec. 116 (1953).

s6 601 F.2d 459 (9th Cir. 1979).

${ }^{37}$ The opinion is not entirely consistent on this point; see, for example, the first two paragraphs on page 465 of the opinion, id. at 465 .

ss Id. at $464-65,467$.

so Id. at $464-65$. 
constitute only a "small and rather exclusive group"40 is simply unfounded. While the group may be rather "exclusive," depending on one's definition of that term, it certainly is not "small": during the year ending September 30, 1977 (the last year for which final figures are available), more than 250,000 aliens were admitted under classifications that permitted them to harbor the intent to reside here permanently, which is necessary to establish "lawful domicile." A discussion and enumeration of these potential "Lok beneficiaries" is appended to this comment. ${ }^{42}$

Aside from the numerical significance of this controversy, the substantive disagreement between the Second and Ninth Circuits centers on four issues: the legislative history of section 212(c), the language and effect of section 212 (c) as it fits into the rest of the statutory scheme, the amount of deference to be accorded longstanding administrative interpretation, and the controlling policy considerations.

\section{The Legislative History of Section 212(c)}

\section{A. An Alternate Construction Rejected}

Each side of the present dispute has sought to support its statutory analysis by resorting to the scant legislative history of section 212(c). The section was enacted in 1952 as part of the comprehensive revision and codification of the immigration, citizenship, and naturalization laws in the Immigration and Nationality Act." Throughout the tortuous drafting of the Act, the language of section 212(c) remained essentially the same. ${ }^{44}$ The only indication that a different formulation ever was contemplated appears in the report of the initial congressional investigation of the immigration laws that led to the 1952 recodification. ${ }^{45}$

A significant concern of this study was the controversial pred-

to Castillo-Felix v. INS, 601 F.2d 459, 465 (9th Cir. 1979).

4 See text and notes at notes 179-181 infra.

22 See text and notes at notes 146-181 infra.

4s Immigration and Nationality Act of 1952, ch. 477, 66 Stat. 163 (1952) (current version at 8 U.S.C. $\S \S 1101-1503$ (1976 \& Supp. II 1978)).

4 See S. 3455, 81st Cong., 2d Sess. § 212(c) (1950); S. 716, 82d Cong., 1st Sess. § 212(c) (1951); H.R. 2379, 82d Cong., 1st Sess. § 212(c) (1951); H.R. 2816, 82d Cong., 1st Sess. $\S 212$ (c) (1951); S. 2550, 82d Cong., 2d Sess. $\S 212$ (c) (1952). The minor changes that these drafts did undergo concerned only which specific subsections were waivable and whether the Attorney General or the Commissioner of the INS was to exercise the discretion.

ts S. Rep. No. 1515, 81st Cong., 2d Sess. (1950). 
ecessor to section 212(c), the so-called seventh proviso, ${ }^{48}$ which provided that "aliens returning after a temporary, absence to an unrelinquished United States domicile of seven consecutive years may be admitted in the discretion of the Secretary of Labor and under such conditions as he may prescribe."47 In concluding its analysis of the faults of the seventh proviso, the Senate Judiciary Committee noted one possible improvement.

The suggestion was made that if the words "established after a lawful entry for permanent residence" were inserted in the seventh proviso to qualify the domicile of the alien it would effectively eliminate practically all of the objectionable features, and at the same time the Attorney General would be left with sufficient discretionary authority to admit any lawfully resident aliens returning from a temporary visit abroad to a lawful domicile of seven consecutive years. ${ }^{48}$

This suggestion, had it been enacted, would have required the interpretation adopted by the BIA in In re Anwo and by the Ninth Circuit in Castillo-Felix. Consequently, the argument has been made that the Committee's apparent rejection of this clearer language mandates the contrary interpretation, that is, the one reached by the Second Circuit in Lok. ${ }^{49}$

A complete reading of the Committee's report, however, indicates that there was in fact no consideration of the precise question at issue here. The Committee's sole concern was in restricting the seventh proviso so that only those aliens "who came in the front door, were inspected, lawfully admitted . . . and remained here for 7 years before they got into trouble"so would be eligible for relief. Two major defects in the seventh proviso's interpretation and application up to that time were discussed: aliens entering

to Act of Feb. 5, 1917, ch. 29, $\S 3,39$ Stat. 878 (repealed 1952). This statute was the seventh proviso to section 3.

17 Id. "Attorney General" replaced "Secretary of Labor" in a later amendment. See S. Rep. No. 1515, 81st Cong., 2d Sess. 382 (1950).

ts S. REP. No. 1515, 81st Cong., 2d Sess. 384 (1950).

19 Lok v. INS, 548 F.2d 37, 40-41 (2d Cir. 1977). The Ninth Circuit's response to this was that the Committee members "might have considered [the proferred language] superfluous, believing that the enacted version adequately conveyed their intent that admission for permanent residence precede the seven years of domicile." Cestillo-Felix v. INS, 601 F.2d 459,465 (9th $\mathrm{Cir}$. 1979). This supposition seems inconsistent with the court's declaration in the very next sentence that section $212(c)$ is at best "an ambiguous provision" on its face. Id.

so S. Rep. No. 1515, 81st Cong., 2d Sess. 382 (1950). 
fraudulently or without inspection were being granted relief, and aliens previously deported were being readmitted. ${ }^{\text {s1 }}$ The report contains no discussion of whether relief should be available to nonimmigrants adjusting their status to that of permanent residents, ${ }^{52}$ or to aliens otherwise able to establish lawful domicile without being permanent residents. ${ }^{. s} \mathrm{By}$ merely adding the requirements that the alien be "lawfully admitted for permanent residence," that the absence be a "voluntary" one, and that the seven years of domicile be "lawful," the Committee apparently was concerned only with correcting the two "defects" mentioned in the report.

\section{B. Contemporaneous Enactments}

Although Congress declined to adopt the clearly more restrictive wording of section 212(c) suggested to the Senate Judiciary Committee, at the same time it did enact a naturalization provision that reads much as section 212 (c) would have, had the "suggestion" discussed above in fact been adopted: "No person ... shall be naturalized, unless such petitioner, (1) . . . has resided continuously, after being lawfully admitted for permanent residence, within the United States for at least five years . . . ."144 Thus it becomes at least arguable that, had Congress intended the seven years of lawful domicile to accumulate only after lawful entry for permanent residence, it would have said so more clearly, as it did in this naturalization provision. ${ }^{s 5}$ On the other hand, this argument does not fully validate the contrary-that Congress intended aliens to be able to tack on nonpermanent-resident years to meet the seven-year requirement-for that intention could just as easily have been expressed in somewhat clearer language as well.

\section{Congress's Restrictive Intent}

The Ninth Circuit made a different type of argument from the legislative history, based on what it perceived to be Congress's re-

${ }^{51}$ Id. at $382-83$.

52 The Committee spoke critically of granting relief to aliens who entered "with a fraudulently obtained visa, with a forged visa, or without a visa," id. at 382 , but did not mention aliens who entered with a nonimmigrant visa.

bs Examples of this group would be refugees and parolees. See text and notes at notes 174-178 infra.

B4 8 U.S.C. \& 1427(a) (1976) (emphasis added). See Immigration and Naturalization Service, Analysis of S. 3455, at 212-13 (1950) (available in the INS's Washington office).

ss See Lok v. INS, 548 F.2d 37, 41 (2d Cir. 1977). 
strictive intent in passing section 212(c). When Congress enacted the section by amending the seventh proviso, its purpose in inserting "lawful" before "domicile of seven consecutive years" was to prevent misuses of the seventh proviso by cutting back on its applicability. ${ }^{58}$ Therefore, the Ninth Circuit argued, this restrictive purpose should control the general interpretation of section 212(c)..$^{.7}$

This argument fails for three reasons. First, the 1952 amendment was not entirely restrictive; in some respects, relief was expanded by enactment of section 212(c). As the INS General Counsel explained,

[t]he 7th proviso is applicable only to those cases of aliens who are excludable on some grounds appearing in the 1917 Act, as amended. It has not been used to authorize admission of aliens who are excludable under the 1924 Act. . . . [Section 212(c)] refers to the granting of discretionary relief not only with respect to such matters as arise under the 1917 and related Acts, but also with respect to the grounds of exclusion which, under existing law, arise under the 1924 Act. $^{58}$

Second, although Congress did intend to restrict the seventh proviso, it also intended to continue relief to cases that came within the newly defined section 212 (c) and thus "there appears to be no intention to restrict the generally beneficent approach applicable to relief provisions." Third, if the restrictive purpose of an amendment to an otherwise ameliorative statute were to control the statute's construction, the interpretation of the statute might change radically and arbitrarily every time a minor amendment to it is adopted.

In sum, the specific legislative history of section 212(c), though containing shreds of support for both interpretations, is essentially inconclusive. ${ }^{60}$ The surest indication of the truth of this statement is that while one tribunal thought that one interpretation was sup-

so See text and notes at notes 50-52 supra.

${ }^{87}$ Castillo-Felix v. INS, 601 F.2d 459, 465-66 (9th Cir. 1979).

ss Immigration and Naturalization Service, supra note 54, at 212-33.

so Kramer, supra note 21 , at 529.

so Cf. Costello v. INS, 376 U.S. 120, 125 (1964) ("There is nothing in the legislative history of $\S 241(\mathrm{a})(4)$ [of the Act] of so specific a nature as to resolve the ambiguity of the statutory language"). 
ported by this history, ${ }^{61}$ another found that this same history clearly mandated the contrary result. ${ }^{62}$

\section{The Statutory Context of Section 212(c)}

In attempting to determine the correct construction of a statutory section, it is often important not only to examine the specific legislative history of that section, but also to view it within an overall statutory context. ${ }^{\text {ss }}$ The BIA and the Ninth Circuit have made two such arguments in support of their restrictive reading of section 212(c).

\section{A. The Pattern of Discrimination Against Nonimmigrants}

The first of these arguments is premised upon the Act's general pattern of discrimination against nonimmigrants. The BIA observed in In re Anwo ${ }^{64}$ that whereas the lawful permanent resident has met extensive standards for admission, looks toward eventual citizenship, and may be employed, the nonimmigrant is usually limited to a relatively short visit to this country. From these observations, the BIA concluded that "[i]t is not reasonable to believe that the Congress visualized [the nonimmigrant] as remaining here for years, until such time as he could achieve lawful permanent residence, and thus qualify for the benefits of section 212(c)."'Bs

There are several defects in this argument. First, what is at issue is not whether nonimmigrants will be allowed section 212(c) relief, but whether lawful permanent residents ${ }^{68}$ will qualify for such relief if during part of their seven years of domicile they were nonimmigrants. Thus the statutory scheme is relevant only to the extent that it manifests discrimination based on the length of time that an alien has been a lawful permanent resident. There are only two instances, however, in which a specific number of years as a lawful permanent resident is a prerequisite to specific benefits-naturalization $^{67}$ and medicare coverage ${ }^{68}$ - and the latter is ir-

-1 In re S., 5 I. \& N. Dec. 116, 118 (1953).

"2 Lok v. INS, 548 F.2d 37, 41 (2d Cir. 1977).

6s "[T]he meaning of a statute is to be looked for, not in any single section, but in all the parts together . . . " Panama Ref. Co. v. Ryan, 293 U.S. 388, 439 (1935) (Cardozo, J., dissenting).

s4 16 I. \& N. Dec. 293 (1977), aff'd per curiam, 607 F.2d 435 (D.C. Cir. 1979).

85 Id. at 296.

${ }^{88}$ It is clear that before a nonimmigrant alien is eligible for section $212(c)$ relief, he must adjust his status to that of a lawful permanent resident.

678 U.S.C. \& 1427(a) (1976). 
relevant to this discussion because it was not imposed until after Congress enacted section 212(c). ${ }^{69}$ Otherwise, lawful permanent residents are granted benefits equally, regardless of the number of years in that status, and correctly so since they have all "met [the same] extensive quantitative and qualitative standards"70 irrespective of whether their status was acquired originally upon entry or later through adjustment of status.

Second, the ostensibly temporary nature of a nonimmigrant's tenure in the United States does not make it unreasonable that Congress envisaged him as eventually "qualify[ing] for the benefits of section 212(c)." ${ }^{\text {"11 }}$ As shown in the Appendix, ${ }^{72}$ it is not necessarily the case that every nonimmigrant "is expected . . . to leave within a relatively short period of time." Certain classes of nonimmigrants are admitted indefinitely and others are allowed multiple extensions of stay; Congress "was willing to allow [these] aliens to adopt the United States as their domicile."74 Moreover, Congress could not have considered entry as a nonimmigrant an absolute bar to section 212(c) relief, because even under the more restrictive interpretation embraced by the BIA a nonimmigrant would become eligible for such relief seven years after adjustment to permanent residency status.

Third, although Congress did discriminate between lawful permanent residents and nonimmigrants as to those rights enumerated by the $B I A,{ }^{75}$ the duties, responsibilities, and disabilities of the two are nevertheless largely the same. All aliens are equally subject to the grounds for deportation ${ }^{76}$ and must register each year. ${ }^{77}$ No alien can vote, hold office, or serve on a jury, and those nonimmigrants who remain for more than one year are presumed

a 42 U.S.C. § 426a(a)(4) (1976). See 1 C. Gordon \& H. Rosenfield, Immigration LaW AND Procedure § 1.36, at 1-178 (rev. ed. 1979).

os Social Security Amendments of 1965, Pub. L. No. 89-97, \& 103(a)(4), 79 Stat. 33 (1965) (codified at 42 U.S.C. $\$ 426 \mathrm{a}(\mathrm{a})(4)$ (1976)). It is not codified with the Act, either, and thus is not part of the statutory scheme.

${ }^{70}$ In re Anwo, 16 I. \& N. Dec. 293, 296 (1977), aff'd per curiam, 607 F.2d 435 (D.C. Cir. 1979).

71 Id.

72 See text and notes at notes $156-171$ supra.

73 In re Anwo, 16 I. \& N. Dec. 293, 296 (1977), aff'd per curiam, 607 F.2d 435 (D.C. Cir. 1979).

74 Elkins v. Moreno, 435 U.S. 647, 666 (1978).

${ }^{23}$ See text at note 65 supra.

7* Gordon, Finality of Immigration and Nationality Determinations-Can the Government be Estopped?, 31 U. CHI. L. REv. 433, 439 (1964).

771 C. GoRdon \& H. Rosenrield, supra note 68 , at $\S 1.40$. 
residents and treated, for tax purposes, as lawful permanent residents. ${ }^{78}$

Finally, reasoning from the premise of the pattern of discrimination against nonimmigrants to the conclusion of the more restrictive BIA-Ninth Circuit interpretation of section 212(c) is unsound because it contains an incorrect second premise, namely, that only nonimmigrants will benefit from the more expansive Lok interpretation. In fact, a significant number of immigrants stand to benefit from the Lok interpretation: parolees and refugees. ${ }^{79}$ The disparate treatment of permanent residents and nonimmigrants thus provides little support for the BIA's restrictive interpretation of section $212(\mathrm{c})$.

\section{B. Disruption of the Scheme of Discretionary Relief}

The BIA's second argument from the statutory scheme is that the $L o k$ interpretation undermines another waiver provision: the aliens benefited by $L o k$ would be able to contest their deportations under section 212(c) and thereby avoid the much more rigorous requirements for waiver of deportation under section $244(\mathrm{a}),{ }^{80}$ the principal section governing such waivers.

This argument also is unpersuasive. First, it is not Lok that primarily extends section 212 (c) into the deportation field, but rather Francis $v$. INS, where the court held that applying section 212(c) only in certain deportation situations denied other deportees equal protection. ${ }^{81}$ After Francis, then, an alien with seven

${ }^{78}$ Id. $\S 1.38$, at $1-186 ;$ id. $\S 1.42$, at $1-190$.

${ }^{79}$ See text and notes at notes 174-179 infra. The statute is less clear on the relative rights, duties, and disabilities of refugees and parolees as opposed to those of permanent residents. Yet one strong indication that all refugees and certain parolees are to be accorded treatment equal to that of lawful permanent residents is that the adjustment-of-status section written specifically for these classes makes the adjustment to lawful permanent residence retroactive. See note 178 infra. Thus, they are given "credit" for their years as refugees in meeting the five years of lawful permanent residence requirement for naturalization. But see Comment, Extending the Constitution to Refugee-Parolees, 15 SAN Diego L. Rev. $139,142-52$ (1977) (arguing that there is a distinct "rights gap" between permanent residents and parolees).

Bo 8 U.S.C. $\$ 1254$ (a) (1976). This section imposes two sets of conditions before waiver can be given: one for the less serious grounds for deportation, $i d$. $\S 1254(a)(1)$, and a second, more stringent set for the more serious grounds, $i d$. $\$ 1254(\mathrm{a})(2)$. The more lenient of these two sets requires seven years of residence, a finding of good moral character (as stringently defined in the Act, see $i d$. $\S 1101(f)$ ), and a finding that extreme hardship would be imposed on the alien's family if he were deported. Even then Congress has an opportunity to override the Attorney General's grant of discretion. Id. § 1254(c).

${ }^{81}$ See text and notes at notes 17-19 supra. 
years of lawful permanent residence can obtain a waiver of deportability without meeting the stricter requirements of section 244(a). To give equal treatment to permanent residents who spent part of their seven years as nonimmigrants thus undermines section 244(a) only slightly ${ }^{82}$ and has little effect on the rationality of the Act.8s

Second, the waiver provisions that Congress has provided are not a delicately balanced house of cards that will collapse if one section is disturbed. Even as section 244(a) now stands, it is "undermined" by several other provisions. Sections $102,{ }^{84} 241(f),{ }^{85}$ $245,^{86}$ and $212(d)(5)^{87}$ all allow waiver of some or all of the grounds for deportation with far less rigorous requirements than does section 244(a). ${ }^{88}$ The sections providing for waivers of grounds for ex-

82 See Castillo-Felix v. INS, 601 F.2d 459, 469 (9th Cir. 1979) (Takasugi, J., dissenting). Cf. Tibke v. INS, 335 F.2d 42, 46-47 (2d Cir. 1964) (contention that extension of section 245 relief to immigrants as well as nonimmigrants would make section 244 a "dead letter" proves too much because under this argument section 244(a) already would be a dead letter as to nonimmigrants).

Judge Takasugi also argued in dissent that "[t]here are no real differences in the standards [imposed by section 212(c) and section 244(a)], but only greater articulation of them in $\S 244$ (a)." 601 F.2d at 469 . This does not appear to be an accurate assessment; "good moral character," which is required only by section $244(a)$, is strictly defined in section 101(f) of the Act as excluding, among others, habitual drunkards, adulterers, and gamblers. 8 U.S.C. \& 1101(f)(1)-(2), (4)-(5) (1976). Moreover, the BIA has held that "[t]here is nothing in the law ... which requires an applicant for discretionary relief under section 212 (c) . . to establish good moral character. . . . [T]herefore, the statutory prohibitions as to the establishment of good moral character are not controlling . . . " In re N., 7 I. \& N. Dec. 368, 369 (1956).

ss Indeed, on the reasoning of Francis itself, it could be argued that the denial of equal treatment to such a class is arbitrary and fortuitous, the only difference between the two groups being the type of visa under which they entered the country, and that the Lok interpretation therefore makes the scheme more rational. See text and note at note 70 supra; note 127 infra.

It might also be noted that, considered in conjunction with the Francis decision, the argument does not properly serve as an index of congressional intent in 1952. As written, section 212(c) has no application to grounds for deportation; it speaks only to waiver of grounds for exclusion. Thus, if Congress had intended to permit lawful permanent residents of fewer than seven years to benefit from section 212(c), at the time it was enacted there would have been no undermining of section 244(a). That section 244(a) might now be undermined cannot indicate Congress's probable intentions in 1952.

* 8 U.S.C. $\S 1102$ (1976).

s5 Id. § 1251(f).

os Id. § 1255 .

sz Id. § $1182(\mathrm{~d})(5)$.

section 102 exempts certain foreign government officials and their entourages from virtually all deportation provisions except those for subversive activities. Id. § 1102. Section 241(f) waives fraud during entry as a ground for deportation for any alien with certain relatives in this country. Id. $\S 1251$ (f). Section 245 allows any alien (excepting certain enumer- 
clusion likewise are not self-contained, but overlap to a great extent. $^{89}$ The Second Circuit's expansive reading of section $212(\mathrm{c})$, if it is ill-fitting, will add only one more piece to the already jumbled puzzle. Thus, although it is true that internal consistency has a high value in complicated statutory schemes, the Immigration and Nationality Act-unlike other complex statutes such as the Internal Revenue Code-is already discordant internally. ${ }^{90}$

\section{Deference to Agency Interpretation}

In adopting the INS's interpretation, the Ninth Circuit placed great emphasis on the deference owed to agency interpretation. The practice in the federal courts of deferring to a contemporaneous, ${ }^{91}$ consistently followed interpretation of an ambiguous statute by the administrative agency charged with its enforcement is so

ated classes) to adjust his status, at the Attorney General's discretion, to that of a lawful permanent resident. $I d$. § 1255 . This section thus is incorrectly designated in the United States Code as applying only to nonimmigrants. See Tibke v. INS, 335 F.2d 42, 45 (2d Cir. 1964). This procedure gives the alien the benefit of any waiver-of-exclusion provision for which he is eligible. If the excludable offense being waived is also a deportable offense, then the adjustment effects a waiver of deportation as well. See In re G.A., 7 I. \& N. Dec. 274, 275 (1956); In re L., 1 I. \& N. Dec. 1, 6 (1940). To make this somewhat clearer, it should be explained that, unlike section 212(c), other waiver-of-exclusion provisions cannot be used to waive deportable offenses unless the alien leaves the country subsequent to the commission of the deportable or excludable offense and then seeks to reenter. This path may be foreclosed once deportation proceedings are instituted, however, since aliens deportable on certain grounds are not allowed to leave the country voluntarily. 8 U.S.C. $\S 1252$ (b), (c) (1976). Thus, without the fiction of the adjustment process that the alien is "entering" the country, the alien could not take advantage of the waiver-of-exclusion provision.

Section $212(d)(5)$ in effect waives all grounds of deportation for parolees. Id. $\S 1182(d)(5)$. Although the statute does not expressly say this, it necessarily follows because only aliens who have entered the country can be deported, see id. $\S 1251$ (a), and by a legal fiction parolees are deemed not to have entered the country despite their physical presence, Leng May Ma v. Barber, 357 U.S. 185, 189-90 (1958).

o' See 8 U.S.C. \$§ 1102, 1182(b), 1182(d)(1), 1182(d)(3), 1182(d)(5), 1182(g), 1182(h), 1182(i), and 1183 (1976); Refugee Relief Act of 1980, Pub. L. No. 96-212, § 1(c)(3), 94 Stat. 104 (1980) (to be codified at 8 U.S.C. \$ 1157(c)(3)).

'o See Castillo, Introduction, 15 San Diego L. Rev. 5, 5 (1977) ("The immigration laws ... remain a murky maze of seemingly contradictory passages, granting a benefit in one section and taking it away in another") (Leonel J. Castillo was Commissioner of the Immigration and Naturalization Service until his resignation on October 1,1979$)$. Cf. Address by Leonel J. Castillo before the National Press Club (Aug. 30, 1979), reprinted in 56 INTERPRETER RELEASES 462, 464 (1979) ("Unfortunately, the major problem with current immigration policy is that it reflects no planning or conscious expression of national intent. Our country has simply drifted into it. There is no clear direction indicated by this policy as to what we as a country expect to achieve through immigration.").

21 In this context, "contemporaneous" means shortly after the statute's enactment. 
well established as to have become a canon of construction. ${ }^{92}$ The rationale for this practice is that the "agency is thought to be more competent . . . because of its specialized knowledge and experience, capacity to seek out and evaluate opposing interests and points of view, direct familarity with administrative needs, [and] greater accountability to Congress."9s

At first, it appears that a strong case could be made for deferring to the INS's interpretation in this controversy. It originated in an opinion of the BIA in the 1953 case of In re $S .{ }^{94}$ it was thus adopted only one year after the statute's enactment ${ }^{95}$ by an agency that "played an important role in the statute's drafting." The INS's interpretation ${ }^{97}$ is of long standing, ${ }^{88}$ having remained unchanged since $1953 .{ }^{99}$ The agency making the interpretation is charged with administering the Act and promulgating necessary regulations, ${ }^{100}$ and is therefore intimately concerned with the practical importance of the interpretation. Finally, the interpretation was made in the context of an adversary proceeding ${ }^{101}$ and thus presumably was made after full development of the competing considerations for each possible interpretation. ${ }^{102}$ When one examines the origins of the INS interpretation more closely, however, it becomes apparent that many of these considerations are illusory.

First, it appears upon closer analysis that the language in In re $S$., which was relied upon by the BIA and the Ninth Circuit as setting the 1953 precedent dispositive of the instant question, was no "interpretation" as all. Rather, it was written inadvertently and

?2 See 2A J. Sutherland, Statutes and Statutory Construction $\$ 49.05$, at 241 n.5 (4th ed. 1972); id. at 31 n.5 (Supp. 1979).

${ }^{93}$ Note, The Authority of Administrative Agencies to Consider the Constitutionality of Statutes, 90 HARv. L. REv. 1682, 1695 (1977).

* 5 I. \& N. Dec. 116 (1953).

os See 2A J. SUTHERLAND, supra note 92 , at $\$ 49.03$ ("contemporaneous . . . interpretation ... constitutes an invaluable aid"); note 91 supra.

- See text at notes 53-54 supra.

97 To avoid confusion, the interpretation or arguments adopted by the BIA will be referred to as the INS's position as well, regardless of whether the INS in fact argued for the position when it was before the Board. See note 25 supra.

s Cf. 2A J. SutherLand, supra note $92, \S 49.03$ ("Long-continued . . . interpretation ... [is] an invaluable aid").

- Castillo-Felix v. INS, 601 F.2d 459, 465 (9th Cir. 1979).

${ }^{100}$ See authorities cited note 5 supra.

102 See text and notes at notes 25-28 supra. Since the BIA and the INS are separate entities, the Board plays a neutral role.

${ }^{102}$ Cf. 2A J. SutherLaNd, supra note $92, \S 49.05$ ("The source or origin of . . . interpretation has an important bearing upon the probative force that will be accorded such interpretation in the process of statutory construction"). 
without contemplation of the precise syntactical question discussed in this comment, much as Congress did not consider these issues when it enacted section $212(\mathrm{c}) .^{103}$

The alien in In re $S$. had been lawfully admitted for permanent residence in 1949 but had resided in the United States for eight years prior to 1949 in an apparently unlawful status. ${ }^{104}$ In 1953 he was denied advance permission to reenter the country. ${ }^{105}$ This situation presented two possible grounds upon which the BIA could deny the alien section 212 (c) relief. The broader, more apparent ground would be that his seven years of domicile had not been "lawful" because his original entry in 1941 was not a lawful one. The narrower and less obvious ground would be that he had not been an "alien lawfully admitted for permanent residence" for seven years. Only the first of these two is clearly a ground for disqualification on the face of section 212(c), and, judging from the opinion, it appears that only the former was contested by the alien.

[T] he applicant argues that [section 212(c)] should be construed as applying to persons who are returning to a lawful domicile and that said domicile is unrelinquished and has existed for not less than seven consecutive years . . . . To put it another way, the alien's contention would appear to be that inasmuch as he has a lawful permanent residence to which he is returning, and inasmuch as he has an unrelinquished domicile in the United States for more than 7 years past he satisfies the requirements of section 212(c), and that it is not necessary that the 7 years unrelinquished domicile be made up only of domicile accumulated subsequent to a lawful entry for permanent residence. ${ }^{108}$

To put it yet another way, the alien was contending that his domicile prior to his lawful admission for permanent residence need not be lawful. He had no reason to contend that lawful domicile prior to admittance for permanent residence counts toward the sevenyear period-the Lok contention-because his residence between

${ }^{103}$ See text and notes at notes 43-62 supra.

1045 I. \& N. Dec. 116, 116 (1953). The 1949 "entry," then, was actually an adjustment of status.

$105 \mathrm{Id}$. That is, he was in the country at the time and had applied for a ruling as to whether he would be readmissible if he were to leave. It is not entirely clear what disability he had that would prevent readmission, but apparently it was having committed perjury in 1940 and 1941, the same offense that made his original entry in 1941 unlawful. Id.

108 Id. at 117-18. 
1941 and 1949 clearly was not lawful.

Based on its view of the "plain language" of section 212(c), and the relevant legislative history, ${ }^{107}$ the BIA responded to the alien's contentions by concluding that the section was "available only to those lawfully resident aliens who are returning to an unrelinquished domicile of 7 consecutive years subsequent to a lawful entry" and that, in other words, "the alien . . . must have resided in this country for 7 consecutive years subsequent to a lawful entry" and that, in other words, "the alien ... must have resided in this country for 7 consecutive years subsequent to such lawful admission for permanent residence, and ... not only the admission must be lawful but . . . the period of residence must be lawful."108 Thus the BIA does not appear to be responding to the argument that a "lawful entry" could be effected by an entry under a nonimmigrant status. Indeed, the BIA interchanges the general terms "lawful entry," "lawful admission," and "lawful residence" indiscriminately with the technical term "lawful admission for permanent residence," apparently treating them as equivalent. Therefore, the BIA's statement that "the alien . . . must have resided in this country for 7 consecutive years subsequent to [a] . . . lawful admission for permanent residence," 108 as it affects the instant controversy, is merely unintended dictum. The result is a vitiation of all of those considerations in support of granting deference to the INS position that rely on the longevity and full consideration of the interpretation, the agency's role in the drafting of the statute, and contemporaneity with the enactment. ${ }^{110}$

A second consideration against deferring to this agency interpretation is that it cannot be shown to be of long standing. ${ }^{111}$ The BIA did not reiterate its so-called 1953 interpretation until 1976, when the instant controversy arose, and no showing has been made that immigration officers have consistently applied the interpretation in practice during the interim. ${ }^{112}$ Moreover, even if the INS

${ }^{107}$ The BIA cited those excerpts quoted above in text at note 48 supra. 5 I. \& N. Dec. at 118 .

1035 I. \& N. Dec. at 118-19.

109 Id. at 118.

110 Cf. Federal Maritime Comm'n v. Seatrain Lines, Inc., 411 U.S. 726, 745 (1973) ("the cases do not demonstrate the sort of longstanding, clearly articulated interpretation of the statute which would be entitled to great judicial deference").

${ }^{111}$ Cf. Louisville \& N.R.R. v. United States, 282 U.S. 740, 759 (1931) ("Long continued practice. . . may be persuasive in the interpretation of doubtful provisions").

112 For example, INS's Operations Instructions, the Department of State's Foreign Affairs Manual, and the Code of Federal Regulations are all devoid of any reference to this 
interpretation were shown either to be of long standing or to have been employed in practice, no individual would suffer by a change in the interpretation.

Third, the INS has less expertise on this question than other agencies have in other types of interpretation. ${ }^{113}$ Section 212(c) does not present a purposefully broad or vague phrase that was intended by Congress to be applied in specific situations by the administrative agency, ${ }^{114}$ nor does it present a problem of interpretation requiring detailed scientific or technical expertise that is outside the competence of the court. ${ }^{115}$ Rather, it presents only a complex syntax to be parsed, requiring an ability that resides in no greater degree with the INS than with the courts. ${ }^{116}$ To the extent that the Act's complexity does militate in favor of agency deference, because the proper interpretation arguably can only be had with the benefit of intimate familiarity with the Act, the INS's position is in any event assured of representation in every deportation and almost every exclusion appeal because the INS will be made a party. ${ }^{117}$ Furthermore, there is always the danger that spe-

interpretation. See U.S. Dep't of Justice, Immigration \& Naturalization Service, OperaTIONS INSTRUCTIONS, REgUlations, AND INTERPRETATIONS 874 (1979), reprinted in $1 \mathrm{C}$. Gordon \& H. Rosenfield, supra note 68, at 23-164; 9 U.S. Dep'T of State, Foreign AfFairs Manual, reprinted in 6 C. Gondon \& H. Rosenfield, supra note 68, at 32-633; 8 C.F.R. $\S 212.3$ (1980); 22 C.F.R. § 42.95 (1979).

113 See L. Jaffe, Judicial Control of Administrative Action 576 (1965) (relevant considerations as to when an administrative interpretation should be overturned include "the degree to which the framing of a rule appears to depend on expertise").

114 "Statutes . . . at times embody purposeful ambiguity or are expressed with generality for future unfolding." Frankfurter, Some Reflections on the Reading of Statutes, 47 Colum. L. REv. 527, 528 (1947). Even if the controversy is only over the meaning of a single term, the Supreme Court has said that " "courts, and not [administrators], are relatively more expert," "Barlow v. Collins, 397, U.S. 159, 166 (1970) (quoting Hardin v. Kentucky Utils. Co., 390 U.S. 1, 14 (1968) (Harlan, J., dissenting)), and that the "application of canons of statutory construction" is not "within the special competence" of administrators, 397 U.S. at 156 (concerning whether review can be had at all rather than whether deference should be given on review).

${ }^{115}$ Cf. Railroad Comm'n v. Rowan \& Nichols Oil Co., 310 U.S. 573, 583 (1940) (oil proration problems that "touch matters of geography and geology and physics and engineering ... [p]lainly . . . are not issues for our arbitrament").

${ }^{116}$ Cf. K. Davis, Administrative Law Text § 30.06, at 552 (3d ed. 1972) ("judges, not agencies, are the experts or comparatively the experts in many areas, including . . . judgemade law developed through statutory interpretation [and] most analysis of legislative history").

1178 U.S.C. $\& 1105 \mathrm{a}(\mathrm{a})(3)$ (1976) requires that all actions for review of final orders of deportation "be brought against the Immigration and Naturalization Service." This applies to denials of waiver of deportation as well. See Foti v. INS, 375 U.S. 217 (1963). Review of final orders of exclusion is had by habeas corpus proceedings, 8 U.S.C. $\S 1105 a(b)$ (1976), and is brought against "the person having custody of the [alien]." 28 U.S.C. $§ 2243$ (1976). 
cialization and long experience will "breed parochialism ... a and nurture bias"118 so that, faced with annoying, complex problems and a heavy docket, the BIA might develop the tendency to rule automatically against the alien in doubtful cases. ${ }^{118}$

Finally, a court is always free not to follow an agency interpretation that it finds to be wrong. ${ }^{120}$ Such a finding may result from a conviction that the agency construction will frustrate the congressional policy underlying the statute, ${ }^{121}$ or that the contrary reading generally is "the only faithful" one. ${ }^{122}$ Here, as discussed below, ${ }^{128}$ the contrary reading is more faithful to the basic purpose of the statute. In any event, the greater weight of case law authority is that administrative interpretations are never controlling but merely advisory. ${ }^{124}$

\section{Policy Consmerations}

\section{A. The Purpose of Section 212(c)}

The purpose of section 212(c) is to allow waiver of excludability for reentering aliens who have developed such strong ties to this country that exclusion would be unjustly harsh. ${ }^{125}$ To qualify for consideration for waiver, an alien must be "lawfully admitted for permanent residence" and have a "lawful unrelinquished domicile of seven consecutive years."128 These requirements of having a visa status that normally leads to citizenship and of domicile for a minimum number of years are reasonable measures of an alien's attachment to this country and, thus, also of the harshness of excluding or deporting him.

This will usually be the INS District Director. 2 C. GoRdon \& H. RosenfIELD, supra note $68, \S 8.6(\mathrm{c}) ;$ id. $\S 8.7(\mathrm{~b})$, at $8-32$.

118 Note, supra note 93 , at 1697.

110 But see Roberts, supra note 25 , at 39 , who observes:

A narrow and literal reading of the statutes would make the Board's task much easier. The temptation to reach for simplistic solutions always exists, leaving to the reviewing courts the option to take corrective action where more sophisticated or daring techniques may be appropriate. To its credit, the Board traditionally has not taken the easy path but has invested the time and effort needed to work out reasonable answers to vexing and complex problems.

${ }^{120}$ Espinoze v. Farah Mfg. Co., 414 U.S. 86, 94-95 (1973).

121 NLRB v. Brown, 380 U.S. 278, 291 (1965).

${ }^{122}$ See L. JAPrE, supra note 113, at 572.

${ }^{123}$ See text and notes at notes 125-128 infra.

${ }^{124}$ See 2A J. SutherLAND, supra note $92, \S \S 49.03,49.05$.

123 See text and notes at notes 13-14 supra.

${ }^{128} 8$ U.S.C. \& 1182(c) (1976). 
By counting only years of domicile accrued after gaining permanent resident status, the INS destroys the rationality of these criteria. For example, under the INS interpretation, a foreign investor nonimmigrant who is lawfully domiciled here for ten years, is subsequently granted permanent resident status, and who then lives here another six years does not qualify for section 212(c) relief even though there is no reason to suppose that he is any less attached to this country than is an alien who lives here just seven years after an initial entry as a permanent resident. ${ }^{127}$ The number of years of physical presence in the country is much more relevant to determining "attachment" than is the alien's visa classification during the initial years. ${ }^{128}$ The INS interpretation of section $212(\mathrm{c})$ thus restricts the application of the clause in a manner inconsistent with its purpose.

\section{B. Avoidance of Hardship}

The result of a denial of consideration for section 212 (c) relief is the deportation or exclusion of a long-time resident. The Supreme Court has noted on a number of occasions that although deportation is technically not a criminal punishment, ${ }^{129}$ it is nevertheless a "drastic measure,"1so "the equivalent of banishment or exile,"1s1 and "undoubtedly a harsh sanction that has a severe penal effect."192 Quite apart from the consideration of effectuating section 212(c)'s ameliorative purpose, then, there is an additional policy in favor of the Lok interpretation that doubts in the construction of a statute are to be resolved " against the imposition of a harsher punishment." "1ss

${ }^{127}$ In fact, there is reason to treat such an alien more leniently. Not only would his period of domicile in the country be longer but he would have a period of proven exemplary behavior, at least during the first ten years of his domicile. See id. $\S 1255$ (a) (an alien must be found currently qualified for entry and thus meet the rigorous entrance requirements to adjust his status). In contrast, the alien who enters as a permanent resident might commit a series of deportable offenses throughout his seven years of domicile and still qualify for section 212(c) relief because the "lawfulness" of an alien's domicile does not terminate until an actual finding of deportability. See note 22 supra.

328 Congress's acceptance of this notion is seen in section 244 of the Act, 8 U.S.C. $\S 1254$ (1976), a general waiver of grounds for deportation, where Congress required seven (or, in certain instances, ten) years of physical presence, and not any specific number of years of permanent residence.

129 See, e.g., Bridges v. Wixon, 326 U.S. 135, 147 (1945).

130 Fong Haw Tan v. Phelan, 333 U.S. 6, 10 (1948).

131 Delgadillo v. Carmichael, 332 U.S. 388, 391 (1947).

132 Trop v. Dulles, 356 U.S. 86, 98 (1958).

${ }^{193}$ Bonetti v. Rogers, 356 U.S. 691,699 (1958) (quoting Bell v. United States, 349 U.S. 
This is a salutary presumption because it assures fairness to the alien by requiring statutes to give "clear and unequivocal warning in language that people [can] understand,"1s4 and the more so here because aliens usually are less familiar with our language. ${ }^{195}$ Also, if one is to err, a mistake in favor of the alien is preferable because the INS has more ready access to the legislative process and can thus more easily have its desired interpretation enacted. ${ }^{138}$ Finally, this presumption against a harsh reading of the statute is especially appropriate for section 212 (c) because this section does not extend the waiver of exclusion or deportation to all who come within its provisions but only grants the Attorney General the authority to dispense such relief in his discretion. The $L o k$ interpretation will not capriciously afford relief to those who are not deserving; through the Attorney General's control, only those aliens Congress meant to benefit will benefit.

The strength of this policy of construing doubtful deportation statutes in favor of the alien is seen in practice where the federal courts have used it to such an extent that it has now become a widely recognized rule of construction. ${ }^{137}$ It was enunciated sua sponte by the Supreme Court in Fong Haw Tan v. Phelan ${ }^{138}$ even

81, 83 (1955) (Frankfurter, J.)). See also United States ex rel. Eichenlaub v. Shaughnessy, 338 U.S. 521, 533 (1950) (Frankfurter, J., dissenting) ("I deem it my duty not to squeeze the Act . . . so as to yield every possible hardship of which its words are susceptible").

194 3 J. SUTHERLAND, supra note 92 , at $\$ 59.03$.

${ }^{195}$ Cf. Roberts, The Grounds of Deportation, Statute of Limitations on Deportation, and Clarification of the Nature of Deportation, 57 INTERPRETER RELEASES 157, 161 (1980) ("deportation statutes have developed into a highly technical and utterly confusing complex of provisions that only a highly skilled attorney can confront with any degree of confidence").

196 This argument is made in Wenzell \& Kolodny, Waiver of Deportation: An Analysis of Section 241( $f)$ of the Immigration and Nationality Act, 4 CAL. W. INT'L L.J. 271, 305 (1974). Indeed, the INS has an opportunity to recommend changes and clarification. "There is now underway a study by the newly formed Select Commission on Immigration and Refugee Policy that is expected to recommend sweeping changes in the Immigration and Nationality Act, in immigration regulations and overall U.S. policy." Address by Leonel J. Castillo, supra note 90 , at 465 .

${ }^{237}$ See Costello v. INS, 376 U.S. 120, 128 (1964) (one of the "accepted principles of statutory construction in this area of law"); Marino v. INS, 537 F.2d 686, 691 (2d Cir. 1976) ("specific rule[] of statutory interpretation ... in the immigration context"); Lennon v. INS, 527 F.2d 187, 193 (2d Cir. 1975) ("settled doctrine"). See also Costello v. INS, 376 U.S. 120, 128 (1964)(alternate holding); Bonetti v. Rogers, 356 U.S. 691, 699 (1958); Barber v. Gonzales, 347 U.S. 637, 642-43 (1954); Fong Haw Tan v. Phelan, 333 U.S. 6, 10 (1948); Mashi v. INS, 585 F.2d 1309, 1315-16 (5th Cir. 1978); Castaneda de Esper v. INS, 557 F.2d 79, 81 (6th Cir. 1977); Wadman v. INS, 329 F.2d 812, 816-17 (9th Cir. 1964); Wood v. Hoy, 266 F.2d 825, 830 (9th Cir. 1959).

139 333 U.S. 6 (1948). 
though the Court could have reached the same result by relying on the deference-to-agency-interpretation rule. ${ }^{139}$ Furthermore, this rule has been used by a number of courts specifically in regard to the construction of waiver provisions. ${ }^{140}$

In concluding this discussion of the policies favoring the avoidance of hardship, it should be noted that, though most courts have not adopted the rule of liberally construing deportation statutes "out of any sentimental consideration, or for want of sympathy with the purpose of Congress in proscribing evil or antisocial conduct," 141 many informed commentators have openly criticized the Act for being unduly punitive. ${ }^{142}$ For example, Leonel J. Castillo, former Commissioner of the INS, has observed that "we are administering a set of archaic laws written more than 25 years ago ... which make it . . . difficult to render justice, as it is seen in today's world."143 Charles Gordon, former INS General Counsel and perhaps the leading scholarly authority on immigration, similarly has noted that because "the immigration laws [were] . . . enacted during a time of Cold War reaction ... . [they] reflect the fears and insecurities, and . . . the punitive impulses of past Congresses."144 Finally, and most graphically, Professors Hart and Jaffe have termed the Act "a bacchanalia of meanness."145 Al-

130 The petitioner alien supported his interpretation with the deference-to-administrative-interpretation rule because the INS consistently had applied a favorable interpretation for eleven years, until shortly before his case arose. See Brief for the Petitioner at 15-16, Fong Haw Tan v. Phelan, 333 U.S. 6 (1948).

110 E.g., INS v. Errico, 385 U.S. 214 (1966) (section 241(f) waiver of fraudulent entry); Yui Sing Tse v. INS, 596 F.2d 831, 835 (9th Cir. 1979) ("the rule . . . is fully applicable where the question is eligibility for adjustment status [sic] rather than deportability"); Giambanco v. INS, 531 F.2d 141 (3d Cir. 1976) (section 245 adjustment of status and section 212(h) waiver of conviction as grounds for exclusion); Tibke v. INS, 335 F.2d 42 (2d Cir. 1964) (section 244 suspension of deportation); Leong Leun Do v. Esperdy, 309 F.2d 467 (2d Cir. 1962) (provision of Refugee Relief Act of 1953, ch. 336, § 6, 67 Stat. 403 (1953) (terminated 1956), allowing adjustment of nonimmigrants who are subject to persecution).

341 Bonetti v. Rogers, 356 U.S. 691, 699 (1958).

142 E.g., Edelstein, The Lehman Immigration Bill, FED. BAR NEWs, June, 1956, quoted in Wasserman, supra note 2, at $260 \mathrm{n.50}$ ("The law is needlessly cruel and replete with extreme punishments for relatively minor acts"); Wasserman, Grounds and Procedures Relating to Deportation, 13 SAN Diego L. REv. 125, 126 (1975) (noting the "severity and arbitrary character of our deportation laws"). See the grounds for exclusion listed in note 9 supra. Cf. Lennon v. INS, 527 F.2d 187, 193 (2d Cir. 1975) (Kaufman, C.J.) ("in severity [deportation] . . . surpasses all but the most Draconian criminal penalties").

${ }^{143}$ Address by Leonel J. Castillo, supra note 90, at 463.

${ }^{244}$ Address by Charles Gordon, Los Angeles County Bar Association seminar on "Practicing Immigration Law in the '80s" (Nov. 10, 1979), reprinted in 56 INTERPRETER RELEASEs $545,545,549$ (1979).

${ }^{145}$ Testimony before the President's Immigration Commission, Oct. 28, 1952, quoted in 
though dissatisfaction with an act of Congress is no excuse for courts to ignore its terms, neither is there any reason to construe a section in an Act almost uniformly criticized for its harshness any more harshly than its terms require.

\section{Conclusion}

The more straightforward reading of section 212 (c) views the two phrases "lawfully domiciled" and "lawfully admitted for permanent residence" as independent requirements and, thuscontrary to the interpretation adopted by the INS-allows years of lawful domicile in other alien statuses to count toward the requisite seven years. The arguments for rejection of this more natural reading are unpersuasive; indeed, there are many reasons to confirm such a reading.

The strongest case for rejecting the INS interpretation is the deference that is usually given to agency interpretations. This rationale is inapplicable here because the INS's asserted 1953 interpretation actually was inadvertent dictum and is not supported by agency expertise, careful consideration of administrative ramifications, or even full adversarial development of the relevant issues.

Judging from the legislative history and the statutory setting of section 212(c), Congress did not consider this question either. It is clear that Congress's concern in enacting section 212(c) was not whether lawful permanent residents who entered as nonimmigrants or refugees would benefit from its relief. Rather, Congress's sole concern was that only lawful entrants should benefit. Moreover, Congress has not provided a consistent statutory scheme, either in regard to relief provisions or in regard to the rights and benefits to be given long-term residents, that could offer a helpful clue concerning its actual or probable intent.

The decision of which interpretation to adopt must therefore turn on an analysis of the purposes of section 212(c). The Lok interpretation's conditioning of eligibility on years of lawful domicile rather than on years of domicile as a permanent resident correlates far better with the amelioration of harshness which the section is meant to effect. Moreover, it is simply unconscionable to deny to the very aliens who meet section 212 (c)'s literal terms the relief that the section was designed to afford. Although more aliens will qualify for consideration for waiver under this interpretation, the

Wasserman, supra note 2, at 255. 
discretionary nature of the Attorney General's approval will ensure that only deserving aliens will have their condition waived. 


\section{Appendix: Potential Lok Beneficiaries}

If one is persuaded by the foregoing analysis that years of lawful domicile accumulated in a status other than that of permanent resident should count toward the seven-year requirement of section 212(c), there remains the important matter of determining the other statuses in which aliens may be found lawfully to harbor the necessary domiciliary intent. There has been some confusion and controversy over this question-as evidenced by an incorrect hypothetical example of such an alien posited by Chief Judge Kaufman in $L o k^{148}$ and Judge Wright's summary characterization of such aliens as constituting a "small and rather exclusive group of nonimmigrants." 147

\section{A. Nonimmigrants}

The principle case standing for the proposition that certain nonimmigrants 148 can lawfully maintain a domicile is Elkins $v$. Moreno. ${ }^{149}$ In that case, two dependent children of nonimmigrant G-4 visa holders ${ }^{150}$ brought a class action suit to challenge the Uni-

146 Chief Judge Kaufman gave as his example of someone who would be eligible for section 212(c) relief only under the Lok interpretation, a nonimmigrant student who resided here for three years, adjusted his status to that of a permanent resident, and then committed a deportable crime four years later. Lok v. INS, 548 F.2d 37, 40 (2d Cir. 1977). As the D.C. Circuit held in Anwo v. INS, 607 F.2d 435 (D.C. Cir. 1979) (per curiam), however, just such a person is not eligible for section 212(c) relief because, even under the Lok interpretation, he cannot maintain a lawful domicile during the first three years. Id. at $437-38$. This is so because a nonimmigrant student must maintain a residence in a foreign country that he has no intention of abandoning, 8 U.S.C. $\S 1101(\mathrm{a})(15)(\mathrm{F})(\mathrm{i})(1976)$; thus, if he in fact had the domiciliary intent necessary for section 212(c) relief, see note 24 supra, then his residence here during the first three years would be unlawful. 607 F.2d at 437 .

147 Castillo-Felix v. INS, 601 F.2d 459, 465 (9th Cir. 1979). See text and notes at notes 39-41 supra and the remainder of this Appendix infra.

145 For a discussion of the domiciliary capabilities of immigrant aliens other than permanent residents, see text and notes at notes 174-178 infra.

149 435 U.S. 647 (1978).

180 The visa classification system is used in Elkins and herein for simplicity's sake. The system is that employed by the consular officials and set forth at 22 C.F.R. $\S 41.12$ (1979). For example, a G-4 visa is issued to aliens seeking to enter as nonimmigrants who are "officers or employees of . . . international organizations [recognized under the International Organizations Immunities Act, 22 U.S.C. \$§ 288-288i (1976)]." 8 U.S.C. § 1101(a)(15) (G)(iv) (1976). It is somewhat misleading, however, to refer to these aliens as "visa holders" once they have entered since it is not the visa that allows nonimmigrants (or immigrants) to remain; rather, a visa (which is always issued by a consular officer in an alien's country of departure) only allows an alien to apply to an immigration official for admission once he has arrived at a United States port of entry. See 22 C.F.R. \$ 41.122(a), (b) (1979). The visa is thus only a tentative, preliminary determination of the section of the Act under which a potential nonimmigrant will be admissible. See generally E. HARPER, IMmigration Laws or 
versity of Maryland's refusal to grant them an in-state tuition preference, a refusal based on the ground that nonimmigrants "cannot acquire the requisite intent to reside permanently in $\mathrm{Ma}$ ryland, such intent being necessary to establish domicile."151 The University's position was that only citizens and aliens lawfully admitted for permanent residence could acquire the requisite intent, even though these respondents had resided in Maryland for ten and fifteen years. ${ }^{162}$ The Supreme Court held that the respondents were not precluded, as a matter of federal law, from establishing the intent necessary for domicile and certified the case for consideration of possible state law restrictions on the establishment of domicile. ${ }^{153}$ The Court reasoned that since Congress explicitly barred holders of some classes of visas from establishing domicile, ${ }^{104}$ "the conclusion . . . is inescapable" that its silence with respect to other visa classifications was "deliberate": "Congress' silence is therefore pregnant, and we read it to mean that Congress ... was willing to allow nonrestricted nonimmigrant aliens to adopt the United States as their domicile."1ss

Although Elkins involved only G-4 aliens, the case would apply to all other classes that are unrestricted as to length of stay or maintenance of a foreign residence. ${ }^{156}$ The following classes of nonimmigrants thus are capable of establishing a lawful domicile before attaining lawful permanent residence status: foreign government officials, their families, and their retinues (A-1, A-2, and A-3 nonimmigrants), ${ }^{167}$ aliens who qualify "to pass in transit to and

The UNITEd States 53, 176 (3d ed. 1975).

131 Elkins v. Moreno, 435 U.S. 647, 653 (1978).

${ }^{102}$ Id. at 652 n.4, 653 .

253 Id. at 666, 668-69. The Maryland Court of Appeals subsequently held that there were no such restrictions. Toll v. Moreno, 284 Md. 425, 444, 397 A.2d 1009, 1019 (1979). See Toll v. Moreno, 441 U.S. 458, 461 (1979) (per curiam).

154 The Court gave as examples visitors for business or pleasure, 8 U.S.C. $\S 1101(\mathrm{a})(15)(B)(1976)$, aliens in immediate and continuous transit, id. $\S 1101(\mathrm{a})(15)(\mathrm{C})$, vessel crewmen, $i d$. $\S 1101(\mathrm{a})(15)(\mathrm{D})$, students, $i d$. $\S 1101(\mathrm{a})(15)(\mathrm{F})$, and temporary workers, id. $\S 1101(\mathrm{a})(15)(\mathrm{H})(\mathrm{ii}) .435$ U.S. at 665.

$15 s$ U.S. at 666 .

${ }^{168}$ Cf. 19 HARv. INT'L L.J. 1031, 1032 (1978) ("The potential repercussions of [Elkins] . . . upon other rights and obligations may be quite broad").

1378 U.S.C. § 1101(a)(15)(A)(i)-(iii) (1976).

The Elkins opinion relied to some extent on the fact that "Congress's intent [to allow certain nonimmigrants to adopt the United States as their domicile was] . . . confirmed by the [INS] regulations . . . which provide that G-4 aliens are admitted for an indefinite period . . ." 435 U.S. at 666. The Court was referring to 8 C.F.R. $\$ 214.1$ (c) (1980), which provides that A-1, A-2, G-1, G-2, G-3, and G-4 nonimmigrants are admitted for the duration of their status and are not required to obtain extensions of stay. Thus, A-3 nonimmigrants 
from the United Nations Headquarters District" (C-2 nonimmigrants), ${ }^{168}$ officers of, employees of, and representatives to certain international organizations and their families and retinues (G-1 through G-5 nonimmigrants), ${ }^{169}$ and various representatives of NATO member states and their families and retinues (NATO-1 through NATO-5 and NATO-7 nonimmigrants). ${ }^{160}$

Full consideration of the Elkins rationale would not limit its holding only to these groups, however. ${ }^{281}$ The Court reasoned that since some groups are precluded from seeking domicile in the United States, Congress's silence as to other groups was "deliberate" and "pregnant."162 Parallel reasoning can be applied to the fact that some groups are restricted severely as to their intent to stay while others are restricted only slightly. ${ }^{163}$ For example, alien

do not fall strictly within the Elkins holding since they are admitted initially for only one year and must obtain one-year extensions of stay to remain. Id. $\S 214.2(\mathrm{a})$. This is of little import, though, because the Court did not exclude A-3 nonimmigrants from domiciliary capability, 435 U.S. at 663-64, the INS's regulatory confirmation of Congress's intent was a minor point in the Court's overall argument, and such nonimmigrants are not precluded from intending to obtain extensions indefinitely. See 8 C.F.R. § 214.1(a) (1980) ("Every nonimmigrant . . . shall . . . agree to depart the United States at the expiration of his authorized period of admission or extension...." (emphasis added). See also text and notes at notes $163-169$ infra.

1888 U.S.C. $\S 1101(a)(15)(C)(1976)$. As opposed to other C-class aliens, these may remain within the United States indefinitely so long as they stay within a twenty-five mile radius of the United Nations Headquarters. 8 C.F.R. § 214.2(c)(2) (1980).

158 8 U.S.C. $\S 1101(\mathrm{a})(15)(\mathrm{G})(\mathrm{i})-(\mathrm{v})$ (1976); 8 C.F.R. $\S \S 214.1(\mathrm{a}), 214.2(\mathrm{~g})$ (1980); 22 C.F.R. $\$ 41.12$ (1979). The observations in the second paragraph of note 157 supra apply to G-5 nonimmigrants as well.

160 North Atlantic Treaty, Sept. 20, 1951, 5 U.S.T. 1087, 1094-98; Agreement Regarding the Status of North Atlantic Treaty Organization Forces, June 19, 1951, 4 U.S.T. 1792, 1794-96; 8 C.F.R. $\S 214.2(\mathrm{~m})$ (1980); 22 C.F.R. $\$ \$ 41.7(\mathrm{e}), 41.12$ (1979). The NATO visa classes are not themselves categories under which these aliens can enter, see note 150 supra. But see 8 C.F.R. \& 212.2(m) (1980). These officials, however, for the most part would fall within statutorily recognized A-class or G-class entrants. Because statistics for nonimmigrants differentiate between NATO classes and A and G classes the former are mentioned separately here. The NATO-6 class, civilian components of NATO forces, is omitted because it does not appear to fall within any of the A or G classes. NATO forces themselves are not required to obtain visas and specifically are precluded from acquiring domicile. 4 U.S.T. $1792,1796$.

161 The Court held only that G-4 nonimmigrants could establish domicile. It did not rule on which classes could not do so. See 435 U.S. at 663.

182 Id. at 666.

183 Case law supports this general proposition-that nonimmigrants with only minor restrictions on intent can lawfully intend to remain permanently-to the extent that, of the only two authorities that hold that intent to remain permanently is a ground for deportation of nonimmigrants, both concern nonimmigrant classes that are clearly precluded from intending to remain because of severe restrictions. One concerns an alien seaman (D class), 8 U.S.C. § 1101(a)(15)(D) (1976). United States ex rel. Feretic v. Shaughnessy, 221 F.2d 262, 
businessmen and investors (E-1 and E-2 classes) and foreign media representatives (I class) are restricted only as to the vocation or activities they intend to pursue. ${ }^{164}$ The INS concedes that these aliens have domiciliary capabilities. ${ }^{185}$ Some nonimmigrants (classes $\mathrm{E}, \mathrm{I}, \mathrm{L}$, and $\mathrm{K}$ ) are admitted only for a "temporary" period ${ }^{188}$ but are not required to intend to remain temporarily, ${ }^{167}$ in contrast with temporary visitors for business or pleasure (B class), students ( $F$ class), and exchange visitors ( $J$ class); ${ }^{168}$ the former classes are allowed to apply for one-year extensions of stay, apparently indefinitely, and are allowed to adjust their status to that of permanent residents. ${ }^{169}$

Perhaps the strongest argument, however, for the proposition that many nonimmigrants can lawfully intend to remain permanently is this: if they were not free to do so, the section 245 adjustment of status to permanent residence, ${ }^{170}$ as it read at the time of its enactment, would have been vitiated. When enacted, section 245 applied only to "bona fide nonimmigrants."171 Thus, if harboring an intent to become a permanent resident violated every nonimmigrant's status, then no nonimmigrant could have applied for relief under this provision designed exclusively for them.

A final category of nonimmigrants who might benefit only under the Lok interpretation are spouses and children either accompanying or following to join aliens who are in nonimmigrant classes that clearly preclude establishment of domicile. The statuses that impose restrictions regarding maintenance of a foreign

264 (2d Cir. 1955). The other concerns a temporary visitor (B class), 8 U.S.C. $\S 1101(\mathrm{a})(15)(\mathrm{B})$ (1976); In re Safadi, 11 I. \& N. Dec. 446, 447 (1965).

1648 U.S.C. \& 1101(a)(15)(E), (I) (1976).

${ }^{185}$ Castillo-Felix v. INS, 601 F.2d 459, 464 (9th Cir. 1979).

${ }^{186}$ Foreign investors and traders ( $E$ class), foreign media representatives (I class), and intracompany transferees (L class), 8 U.S.C. $\S 1101(a)(15)(E),(I),(L)$ (1976), are admitted for initial periods of one year, 8 C.F.R. $\S 214.2(e)(i)(1)$ (1980). Persons betrothed to American citizens (K class) are admitted for 90 days. 8 U.S.C. $\S 1101(a)(15)(K)$ (1976); 8 C.F.R. $\S 214.2(\mathrm{~K})(1980)$.

187 See 8 C.F.R. § 214.1(a) (1980) ("Every nonimmigrant . . . shall . . . agree to depart the United States at the expiration of his authorized period of admission or extension" (emphasis added)).

${ }^{188} 8$ U.S.C. § $1101(\mathrm{a})(15)(\mathrm{B}),(\mathrm{F}),(\mathrm{J})(1976)$.

${ }^{169} \mathrm{E}-, \mathrm{I}$, and L-class nonimmigrants are allowed extensions of stay. 8 C.F.R. $\S$ 214.1(c), 214.2(e), (i), (l) (1980). K-class nonimmigrants are given a special adjustment of status provision. 8 U.S.C. $\$ 1184$ (d) (1976). All four of these classes have the benefit of the general adjustment of status provision. Id. $\S 1255$.

1708 U.S.C. § 1255 (1976).

171 Immigration and Nationality Act of 1952, ch. 477, § 245, 66 Stat. 217 (1952) (current version at 8 U.S.C. $\$ 1255$ (1976)). 
residence on students ( $F$ Class), exchange visitors ( $\mathrm{J}$ class), and temporary workers ( $\mathrm{H}$ class) do not impose these restrictions on their spouses and children. ${ }^{172}$ Because no time or residence-intention restrictions are placed on these nonimmigrants, they fall within the Elkins doctrine and are capable (as opposed to the student, exchange visitor, or temporary worker himself) of becoming domiciliaries while lawfully retaining their nonimmigrant status. ${ }^{173}$

\section{B. Immigrants Other than Permanent Residents}

In addition to nonimmigrants, parolees and refugees may stand to benefit only from the Lok interpretation. ${ }^{174}$ The Refugee Relief Act of $1980^{175}$ authorizes the admission, as refugees, of aliens who are subject to persecution. ${ }^{176}$ Section 212 (d)(5) of the Immigration and Nationality Act allows the Attorney General to "parole in" aliens at his discretion for "emergent reasons or for reasons deemed strictly in the public interest."17z Both refugees and parolees are here lawfully and are not precluded from harboring the intent to remain permanently or indefinitely. Because they are eligible for section 245 adjustment of status to permanent residence, ${ }^{178}$

172 8 U.S.C. $\S 1101(\mathrm{a})(15)(\mathrm{F}),(\mathrm{J}),(\mathrm{H})(1976)$.

173 Admittedly, this result is somewhat arbitrary.

174 The term "immigrant" is defined so as to include parolees and refugees. See note 7 supra.

178 Pub. L. No. $96-212, \S 201$ (b), 94 Stat. 103 (1980) (to be codified in 8 U.S.C. $\S \S 1157-$ 1159).

170 Id. § 201(a) (amending 8 U.S.C. § 1101(a) (1976)).

1778 U.S.C. $\$ 1182(d)(5)$ (1976).

178 Section 245 applies to any "alien who was inspected and admitted or paroled into the United States." Id. § 1255. The mention of "paroled in" is necessary since parolees are considered as not having entered the country. See note 88 supra.

Actually, not all refugees can be expected to use the discretionary section 245 adjustment of status because there is a separate provision for them that does not require INS approval. Refugee Relief Act of 1980, Pub. L. No. 96-212, § 201(b), 94 Stat. 106 (1980) (to be codified in 8 U.S.C. $\$ 1159(\mathrm{a})(2)$ ). The adjustment is retroactive to the date of the refugee's arrival; it thus arguably allows the refugee to count preadjustment years of domicile towards section 212(c)'s seven-year requirement even under the Castillo-Felix interpretation. Similarly, two uncodified acts allow retroactive adjustment for parolees. The Act of Oct. 5, 1978, 8 U.S.C.A. \& 1182 note (West Supp. 1980), applies to any refugee paroled in before September 30, 1980. The Act of Nov. 2, 1966, 8 U.S.C.A. § 1255 note (West 1970), applies to Cuban parolees who entered after January 1, 1959.

Nevertheless, only 5000 refugees can be given retroactive adjustment per year, Refugee Relief Act of 1980, Pub. L. No. 96-212, § 201(b), 94 Stat. 106 (1980) (to be codified in 8 U.S.C. $\$ 1159(\mathrm{~b})$ ), while 50,000 refugees (or more upon application of the President) may be admitted each year, id. $\$ 201(\mathrm{~b}), 94$ Stat. 107 (1980) (to be codified in 8 U.S.C. $\S 1157(a)(1))$. Parolees will not have a retroactive adjustment provision after September 30, 1980. Thus a significant number of these immigrants can be expected to use section 245 's 
they also could, under the $L o k$ interpretation, become eligible for section 212(c) relief with part of their seven years of domicile accumulated while not permanent residents.

Of all the aliens who enter under these categories, perhaps only a small percentage actually will be in a position in which the alternate constructions of section 212 (c) will matter, since they first must adjust their status to that of permanent residents and they must have exclusion or deportation proceedings brought against them within seven years of such adjustment. The number of aliens entering each year who are not permanent residents but who can lawfully maintain a domicile is large, however-more than 250,000 in 1977 alone $^{178}$-and growing larger each year. ${ }^{180}$ Given this rate of accumulation of potential beneficiaries, the number of actual beneficiaries must be significant. ${ }^{181}$

Mark A. Hall

nonretroactive adjustment.

179 Immigration \& Naturalization Service, 1977 Annual Report 4-6, 71 (1979) (71,216 A class nonimmigrants, 38,235 G class, 5,076 NATO officials, 43,931 E class, 8,361 I class, 7,216 $\mathrm{K}$ class, 32,771 L class, 46,975 F-2, J-2, and H-4 classes, and over 21,000 refugees and parolees) [hereinafter cited as 1977 ANNUAL REPORT].

${ }^{180}$ For example, the number of refugees now authorized is 50,000 per year with discretion in the President to allow an unlimited additional number. See Refugee Relief Act of 1980, Pub. L. No. 96-212, § 201(b), 94 Stat. 103 (1980) (to be codified in 8 U.S.C. $\S 1157(a))$. The total of all nonimmigrants entering per year has increased $800 \%$ over the past 20 years. E. HARPER, supra note 150 , at 668 .

181 An indication of this is that approximately 137,000 aliens in the relevant classes adjusted their status to that of permanent residents in 1977: foreign government offcials-439; treaty traders and investors-1,055; spouses and children of students-1,432; international organization representatives-368; foreign media representatives-43; spouses and children of exchange visitors-1,338; NATO officials-2; parolees-4,493; refugees-129,828. 1977 ANNUAL REPoRT, supra note 179, at 3, 9, 41. 